\title{
D-Lactate Increases Cytokine Production in Bovine Fibroblast-Like Synoviocytes via MCT1 Uptake and the MAPK, PI3K/Akt, and NFkB Pathways
}

\author{
Carolina Manosalva ${ }^{1, \dagger}$, John Quiroga ${ }^{2,3,4,{ }^{\dagger}}$, Stefanie Teuber ${ }^{2}$, Sebastián Cárdenas ${ }^{2}$, \\ María Daniella Carretta ${ }^{2}$, Gabriel Morán G ${ }^{2}$, Pablo Alarcón 2,3 (D, María Angélica Hidalgo 2,* \\ and Rafael Agustín Burgos $2,3, *$ (D) \\ 1 Faculty of Sciences, Institute of Pharmacy, Universidad Austral de Chile, Valdivia 5090000, Chile; \\ carolinamanosalva@uach.cl \\ 2 Laboratory of Inflammation Pharmacology, Faculty of Veterinary Science, Institute of Pharmacology and \\ Morphophysiology, Universidad Austral de Chile, Valdivia 5090000, Chile; john.quiroga@uach.cl (J.Q.); \\ steubervolke@gmail.com (S.T.); sebastian.carvar@gmail.com (S.C.); daniellacarretta@gmail.com (M.D.C.); \\ gmoran@uach.cl (G.M.G.); pabloalarcon.u@gmail.com (P.A.) \\ 3 Laboratory of Immunometabolism, Faculty of Veterinary Sciences, Institute of Pharmacology and \\ Morphophysiology, Universidad Austral de Chile, Valdivia 5090000, Chile \\ 4 PhD Program in Veterinary Sciences, Faculty of Veterinary Sciences, Universidad Austral de Chile, \\ Valdivia 5090000, Chile \\ * Correspondence: mahidalgo@uach.cl (M.A.H.); rburgos1@uach.cl (R.A.B.); Tel.: +56-63-2293212 (M.A.H.); \\ $+56-63-2293015$ (R.A.B.) \\ + These authors contributed equally to this work.
}

Received: 11 August 2020; Accepted: 11 November 2020; Published: 13 November 2020

Simple Summary: Lameness is commonly observed in dairy cattle, affecting animal welfare and farm production. Ruminal acidosis is a metabolic disorder that frequently has been associated with lameness. Has been observed that during acute ruminal acidosis increase the presence of D-lactate in synovial fluid and induces the appearance of a joint inflammation, characterized by an aseptic synovitis. The fibroblast-like synoviocytes is one the main synovium cells involved in the onset of joint inflammation. The aim of this study was to assess the proinflammatory effect of D-lactate on bovine fibroblast-like synoviocytes. We demonstrated that D-lactate increase the release of proinflammatory cytokines, activating intracellular signaling pathways in bovine synoviocytes. Our results support the role of D-lactate in the onset of synovitis and lameness in cattle.

\begin{abstract}
Acute ruminal acidosis (ARA) is caused by the excessive intake of highly fermentable carbohydrates, followed by the massive production of D-lactate and the appearance of neutrophilic aseptic polysynovitis. Bovines with ARA develop different lesions, such as ruminitis, polioencephalomalacia (calves), liver abscess and lameness. Lameness in cattle with ARA is closely associated with the presence of laminitis and polysynovitis. However, despite decades of research in bovine lameness as consequence of ruminal acidosis, the aetiology and pathogenesis remain unclear. Fibroblast-like synoviocytes (FLSs) are components of synovial tissue, and under pathological conditions, FLSs increase cytokine production, aggravating inflammatory responses. We hypothesized that D-lactate could induce cytokine production in bovine FLSs. Analysis by qRT-PCR and ELISA revealed that D-lactate, but not L-lactate, increased the expression of IL-6 and IL-8 in a monocarboxylate transporter-1-dependent manner. In addition, we observed that the inhibition of the p38, ERK1/2, $\mathrm{PI} 3 \mathrm{~K} / \mathrm{Akt}$, and NF-KB pathways reduced the production of IL-8 and IL-6. In conclusion, our results suggest that D-lactate induces an inflammatory response; this study contributes to the literature by revealing a potential key role of D-lactate in the polysynovitis of cattle with ARA.
\end{abstract}


Keywords: ruminal acidosis; D-lactate; fibroblast-like synoviocytes; monocarboxylate transporter; Interleukin 6; Interleukin 8

\section{Introduction}

Acute ruminal acidosis (ARA) or D-lactic acidosis is one of the most severe forms of fermentative disorders in cattle and is caused by an excessive intake of highly fermentable carbohydrate-rich feed [1,2]. D-lactate is usually present in the blood of mammals in nanomolar concentrations due to methylglyoxal metabolism [3,4]. However, in ruminants, an overload of grains leads to the proliferation of carbohydrate-metabolizing bacteria, such as Streptococcus bovis and Lactobacillus spp. [5,6]. The main products of this metabolism are D and L-lactate, which lead to a consequent decrease in ruminal $\mathrm{pH}$ and an increase in lactate-producing bacteria [5]. D-lactate is the predominant enantiomer in the blood of cows with ARA, reaching concentrations of approximately $5 \mathrm{mM}$ [7]. This concentration of D-lactate leads to a deep D-lactic acidemia, and D-lactate distribution to other anatomic compartments that has been associated with the appearance of clinical signs (e.g., diarrhea, depression with weakness, ataxia, coma, tarso-crural joints distention and lameness) [8-11]. Heifers subjected to experimental ARA by the administration of an oligofructose overload develop generalized sterile polysynovitis [1], which is a clinical disorder that is clearly underestimated in cattle lameness during ruminal acidosis $[8,11]$. The aseptic polysynovitis observed in ARA is characterized by the presence of abundant neutrophils and D-lactate concentrations of approximately $6 \mathrm{mM}$ in the synovial fluid [8,9].

Fibroblast-like synoviocytes (FLSs) or type B synoviocytes are mesenchymal cells of the synovial tissue that possess many characteristics of fibroblasts [12]. These cells ensure the structural integrity of the synovial lining and secrete the components of the synovial fluid that are responsible for lubricating the joint [12]. However, under pathological conditions, FLSs produce mediators that induce angiogenesis, cell growth, leukocyte recruitment and immune cell activation, contributing to the exacerbation of the inflammatory response [13-17]. During aseptic joint inflammatory processes, FLSs produce high concentrations of lactate, which has been proposed to be crucial in the intracellular signaling pathway that controls the production of proinflammatory cytokines [18]. An increase in lactate, such as in the cases of acute abdomen disorders, hepatic and renal failure, and diabetic ketoacidosis, is considered a warning sign $[19,20]$. Recently, it has been shown that D-lactate increases neutrophil adhesion to endothelial cells by a mechanism that is dependent on the formation of neutrophil extracellular traps (NETs) [21]. Moreover, monocarboxylate transporter 1 and 2 (MCT1 and MCT2) inhibitors reduce the effects of D-lactate on neutrophils, suggesting that D-lactate needs to be transported into the cells to exert its proinflammatory effects.

In cattle with sterile synovitis induced by ARA, a massive presence of neutrophils and the release of aggregated neutrophil extracellular traps (aggNET) has been observed in synovial fluid [8]. IL-8 is the main cytokine chemoattractant of granulocytes that increased in lamellae tissue in cattle with ARA induced by oligofructose [22] and could be associated with granulocytes-recruitment observed in dermal lamellae [22,23].

Various inflammatory components, such as MMP-9, PGE2, IL-1 $\beta$, and IL-6, have been found in the synovial fluid from cattle with ARA, being the latter the most abundant cytokine [8]. Similarly, in LPS-induced synovitis and lameness in horses, IL-6 is the higher proinflammatory cytokine found in synovial fluid [24]. The mitogen-activated protein kinase (MAPK) and nuclear factor- $\mathrm{B}$ (NF- $\mathrm{kB})$ pathways have been shown to play a predominant role in the expression of proinflammatory cytokines in joint inflammation [25,26]. In addition, bovine IL-6 [27,28] and IL-8 [29] genes contain promoter regions to NF-KB, being mainly upstream regulated by phosphatidylinositol 3-kinase (PI3K) pathway in synoviocytes [30,31].

Since the concentration of D-lactate in the synovial fluid is increased before the recruitment of neutrophils in cows with ARA [9], and IL-6 and IL-8 are the main cytokines that increase in those 
animals, we hypothesized that D-lactate promotes the expression of IL-6 and IL-8 and is dependent on the activation of MAPK, PI3K, and NF-KB in bFLS cells, thus contributing with the inflammatory process observed in synovial tissue [8,9].

\section{Materials and Methods}

\subsection{Fibroblast-Like Synoviocyte Isolation and Culture}

Fibroblast-like synoviocytes were isolated from the carpometacarpal joint of five Black Friesian multiparous dairy cows, $400-500 \mathrm{~kg}$ b.w., obtained from a local slaughterhouse. Joints without injuries such as synovial fluid turbid, presence of fibrin, mucopurulent secretions or hemorrhage, were used. The sample size used in all experiments was estimated from the results obtained previously in bFLS treated with D-lactate [9]. Briefly, we considered an effect size of 3.35, power $=0,95$, and alpha $=0.05$. A minimum sample size of 4 samples for group was calculated using G Power 3.1. Experiments were conducted in accordance with the recommendations of Agencia Nacional de Investigación y Desarrollo based on Chilean Animal Protection Laws. The study protocol was endorsed by the ethical committee of Universidad Austral de Chile (0023/18; Valdivia, Chile).

The synovial membrane was obtained and first digested with $0.2 \%$ type IV collagenase (Thermo Fisher Scientific, Waltham, MA, USA) for $2 \mathrm{~h}$ at $37^{\circ} \mathrm{C}$ with gentle shaking. The suspension cells were seeded in a $75 \mathrm{~cm}^{2}$ flask for propagation. Dulbecco's modified Eagle's medium/Nutrient Mixture F12 (DMEM/F12; Thermo Fisher Scientific) containing 10\% fetal bovine serum (FBS; Biowest, Nuaillé, France) was used. The cells were incubated with $5 \% \mathrm{CO}_{2}$ at $37^{\circ} \mathrm{C}$. FLSs of passages $2-6$ were used for the experiments. To confirm the isolation of bFLSs, CD14 (Becton Dickinson, Franklin Lakes, NJ, USA) and Vimentin (Acris, Herford, Germany) antibodies were used, and the expression of these markers was compared with that in a commercial bFLS line (Articular Engineering, Northbrook, IL, USA). Vimentin is a marker of FLSs and was expressed in both cell lines (Figure S1A) [32]. On the other hand, the absence of CD14 is an FLS marker. Bovine neutrophils (bPMNs) were used as a positive control (Figure S1B) [33]. The isolation of bPMNs was performed as described by Mena et al. [34].

\subsection{Quantitative Real-Time PCR}

bFLSs were seeded in 6-well plates and were treated with vehicle (0.1\% DMSO or H2O), $2 \mathrm{mM}$ or $5 \mathrm{mM}$ D-lactate, $2 \mathrm{mM}$ or $5 \mathrm{mM}$ L-lactate (Sigma-Aldrich, St. Louis, MO, USA) or $100 \mathrm{ng} / \mathrm{mL}$ bovine TNF- $\alpha$ (bTNF- $\alpha$ ) (Thermo Fisher Scientific) for $6 \mathrm{~h}$ at $37^{\circ} \mathrm{C}$ and $5 \% \mathrm{CO} 2$. Prior to stimulation, the cells were incubated with vehicle (0.1\% DMSO) or different inhibitors, namely, $10 \mu \mathrm{M} \mathrm{LY} 294002$ (Sigma-Aldrich) [35,36], $10 \mu \mathrm{M}$ UO126 [36], $10 \mu \mathrm{M}$ BAY 11-7082 (Cayman Chemicals, Ann Arbor, MI, USA) [37], $10 \mu \mathrm{M}$ SB203580 [38], or $1 \mu \mathrm{M}$ Ar-c 155858 (Tocris, Bristol, UK) [21], for $30 \mathrm{~min}$. The supernatant was collected and stored for cytokine detection. Total RNA was extracted from the bFLSs using RNA Kit I (Omega Bio-Tek Inc., Norcross, GA, USA) according to the manufacturer's protocol. RNA was treated with Turbo DNAse (Ambion, Thermo Fisher Scientific) to ensure the removal of genomic DNA. Three hundred nanograms of RNA was reverse transcribed using M-MLV Reverse Transcriptase (Promega, Madison, WI, USA). Real-time PCR was performed in a StepOnePlus ${ }^{\mathrm{TM}}$ (Applied Biosystems, Life Technologies, Foster City, CA, USA) using the Takyon ${ }^{\mathrm{TM}}$ Rox SYBR ${ }^{\circledR}$ master mix (Eurogentec, Seraing, Belgium), and the primers are listed in Table 1. The following conditions were used: 40 cycles at $95^{\circ} \mathrm{C}$ for $30 \mathrm{~s}, 60^{\circ} \mathrm{C}$ for $30 \mathrm{~s}$ (annealing), and $72^{\circ} \mathrm{C}$ for $30 \mathrm{~s}$ (extension); for IL-6, the annealing temperature used was $55^{\circ} \mathrm{C}$. The expression levels of the cytokines and MCTs were normalized to the expression of the housekeeping gene RPS- 9 and then quantified using the $2^{-\Delta \Delta C T}$ method, according to Livak and Smittgen [39], using StepOne ${ }^{\mathrm{TM}}$ v2.3 software (Applied Biosystems). 
Table 1. Sequences of forward and reverse primers.

\begin{tabular}{cccc}
\hline Gene & Forward Primer Sequence $\mathbf{( 5}^{\prime} \mathbf{-} \mathbf{3}^{\prime} \mathbf{)}$ & Reverse Primer Sequence $\mathbf{( 5}^{\prime} \mathbf{- 3}^{\prime} \mathbf{)}$ & Size $^{(\mathbf{B p})}$ \\
\hline bCXCL-1 & CCGCCCCCATGGTTAAGAAA & AAACACAGTCCAGATGGCCC & 161 \\
bCXCL-2 & CCAGCTCTAACTGACCAGGTG & ATGGCCTTAGGAGGTGGTGA & 116 \\
bCXCL-3 & GCCATTGCCTGCAAACTT & TGCTGCCCTTGTTTAGCA & 189 \\
bCXCL-6 & ATTCATCCCAAAACGGTCAGTG & CAGACTTCCCTTCCATTCTTCAAG & 101 \\
bIL-6 & ACTGGCAGAAAATAAGCTGAATCTTC & TGATCAAGCAAATCGCCTGAT & 89 \\
bIL-8 & ATGACTTCCAAGCTGGCTGTTG & TTGATAAATTTGGGGTGGAAAG & 149 \\
bMCT-1 & CGCCGCGAGCCGCGTATAA & CCTCCAACTGCTGGTGGCATTGT & 85 \\
bMCT-2 & CCACCCAGTGCCGGAGACCA & TCCCGTGTCTAAGGTTGCCCAGG & 70 \\
bMCT-3 & GAGGCTGTGGCTGTGCTCATCG & GATCTCGTAGTTCTTGAGCGCGTCC & 72 \\
bMCT-4 & ATCCAGCAAGCCCTCCCTTCCC & CCATGGCCAGGAGGGCTGATTCT & 100 \\
bRPS9 & GCTGACGCTGGATGAGAAAGACCC & ATCCAGCACCCCGATACGGACG & 85 \\
bRPS9 & TTCCAGAGCGTTGGCTTAGG & ACCCTCCAGACCTCACGTTT & 181 \\
\hline
\end{tabular}

\subsection{Immunoblot}

bFLSs were seeded in 6-well plates and were stimulated with $5 \mathrm{mM}$ D-lactate for 0, 2, 5, 10, $15 \mathrm{~min}$ or $100 \mathrm{ng} / \mathrm{mL}$ bTNF- $\alpha$ for $5 \mathrm{~min}$ at $37^{\circ} \mathrm{C}$ and $5 \% \mathrm{CO}_{2}$. Total proteins were obtained as previously described [34], and $30 \mu \mathrm{g}$ of protein was separated using 12\% SDS-PAGE gels and transferred onto nitrocellulose membranes. The membranes were blocked with $5 \%$ skim milk in TBS/T ( $20 \mathrm{mM}$ Tris- $\mathrm{HCl}$, pH 7.6, $137 \mathrm{mM} \mathrm{NaCl}$, and 0.05\% Tween 20) and incubated with anti-MCT1 and anti-MCT4 antibodies (Bioss Antibodies Inc., Woburn, MA, USA) or with phospho-ERK1/2, phospho-p38 or phospho-Akt antibodies (Cell Signaling, Beverly, MA, USA) overnight at $4{ }^{\circ} \mathrm{C}$. Each membrane was incubated with an HRP-conjugated secondary antibody (LI-COR, Lincoln, NE, USA). The bands were visualized using an Odyssey Fc infrared/chemiluminescent detection system (LI-COR Biosciences). After signal detection, the membranes were stripped according to Hidalgo et al. [35] and reprobed with antibodies against total p38 MAPK, ERK1/2, Akt (Cell Signaling, Beverly, MA, USA) or $\beta$-actin-HRP (Santa Cruz Biotechnology, Santa Cruz, CA, USA). The band intensity was measured using Image Studio Lite v5.2 software (LI-COR Biosciences).

\subsection{Quantification of Intracellular D-Lactate in bFLSs by HPLC}

bFLSs were seeded in 6-well plates and were incubated with $5 \mathrm{mM}$ D-lactate for $5 \mathrm{~min}$ at $37^{\circ} \mathrm{C}$ and $5 \% \mathrm{CO}_{2}$. After stimulation, the cells were lysed with liquid nitrogen and $500 \mu \mathrm{L}$ of mobile phase $\left(1 \mathrm{mM} \mathrm{CuSO}_{4}\right)$. The lysate was centrifuged at $18,000 \times \mathrm{g}$ for $20 \mathrm{~min}$ at $4{ }^{\circ} \mathrm{C}$. The supernatant was collected, and the pellet was used for the quantification of total proteins. The supernatant was loaded into Amicon ${ }^{\circledR}$ Ultra-4 3K (Merck Millipore, Darmstadt, Germany) tubes and centrifuged at 75,000 $\times g$ for $40 \mathrm{~min}$ at $4{ }^{\circ} \mathrm{C}$. The filtrates were concentrated in a SpeedVac concentrator (Savant ${ }^{\circledR}$ SPD131DDA, Thermo Fisher Scientific) for $90 \mathrm{~min}$ at $45^{\circ} \mathrm{C}$ and 1.5 atmospheres of pressure. The concentrates were suspended in $200 \mu \mathrm{L}$ of $1 \mathrm{mM} \mathrm{CuSO}_{4}$ and analyzed using HPLC, as previously described [21].

\subsection{Determination of IL-6 and IL-8 by ELISA}

The supernatants obtained from the stimulated bFLSs for the qPCR assay were used to estimate the concentration of proinflammatory cytokines by using bovine IL-8 (\#3114-1A-6, Mabtech, Nacka, Sweden) and IL-6 ELISA kits (\#ESS0029, Thermo Fisher Scientific) according to the manufacturer's instructions. Briefly, the capture antibody was incubated overnight, and the wells were then blocked for $1 \mathrm{~h}$; subsequently, $100 \mu \mathrm{L}$ of sample was added and incubated for $1-2 \mathrm{~h}$. After the plates had been washed twice, the detection antibody was added and incubated for $1 \mathrm{~h}$. After two additional washes, streptavidin was added, and the mixture was incubated for an additional $0.5-1 \mathrm{~h}$. Finally, p-nitrophenyl phosphate ( $\mathrm{pNPP}$ ) or tetramethylbenzidine substrate solution (TMB) was added, followed by incubation for $20-25 \mathrm{~min}$ in the dark. All the procedures were performed at room temperature. The reaction was stopped with $0.16 \mathrm{M} \mathrm{H}_{2} \mathrm{SO}_{4}$ (for IL-6 ELISA Kit), and the samples were analyzed at 405 and $450 \mathrm{~nm}$ for IL-8 and IL-6, respectively, in an automatic Varioskan Flash Reader (Thermo Fisher Scientific). 


\subsection{Determination of $I \kappa B \alpha$ Levels by Flow Cytometry}

bFLSs were seeded in 6-well plates and were stimulated with $5 \mathrm{mM}$ D-lactate for 0, 15, 30, $45 \mathrm{~min}$ or $100 \mathrm{ng} / \mathrm{mL}$ bTNF- $\alpha$ for $15 \mathrm{~min}$ at $37{ }^{\circ} \mathrm{C}$ and $5 \% \mathrm{CO}_{2}$. The cells were collected by centrifugation after trypsinization and were fixed with $4 \%$ paraformaldehyde for $15 \mathrm{~min}$. Next, the cells were washed with PBS and permeabilized with $90 \%$ methanol ice-cold. To analyze the effect on the IкB $\alpha$ levels, the cells were incubated with an AlexaFluor 488-conjugated IкB $\alpha$ mouse mAb (Cell Signaling, Beverly, MA, USA) for $1 \mathrm{~h}$. The cells were analyzed using a FACS Canto II flow cytometer (Becton Dickinson, Franklin Lakes, NJ, USA) and FlowJo 7.6 software (TreeStar Inc., Ashland, OR, USA).

\subsection{Statistical Analysis}

All the assays are shown as the mean \pm SEM of 5 independent experiments. One-way analysis of variance (ANOVA) was performed, and Fisher's LSD multiple comparison test was applied, using a significance level of $5 \%$. When assumptions of normality or homogeneity of variance were not met according to the Shapiro-Wilks or Brown-Forsythe test, respectively, Kruskal-Wallis ANOVA and Dunn's multiple comparison test were used. All the statistical analyses were performed using GraphPad Prism v7.0 (GraphPad Software, La Jolla, CA, USA). A $p$-value $<0.05$ was considered significant.

\section{Results}

\subsection{D-Lactate Increases the Expression of IL-6 and IL-8 in bFLSs}

Previously, we demonstrated an increase in the lactate enantiomers in the joints of cows with ARA $[8,9]$. We observed that D-lactate induced a statistically significant increase in IL-6 and IL-8 mRNA (Figure 1A,B). However, the expression of CXCL-1, CXCL-2, CXCL-3, and CXCL-6 remained unchanged (Figure S2). On the other hand, when we evaluated the effect of L-lactate, there was no increase in the expression of any of the cytokines analyzed (Figure 1A,B; Figure S2). Additionally, the effect of $\mathrm{Na}+\mathrm{D}$-lactate was evaluated, and we observed that $\mathrm{Na}+\mathrm{D}$-lactate significantly increased the expression of IL-6 and IL-8 (Figure S3). bTNF- $\alpha$ was used as a positive control for the expression of proinflammatory cytokines in bFLSs, and we demonstrated an increase in the expression of IL-6, IL-8, CXCL-1, and CXCL-2 (Figure 1A; Figure S2).

A

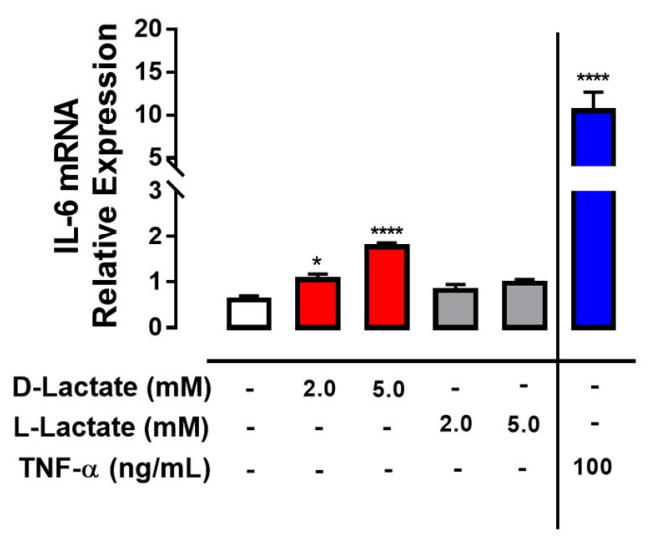

B

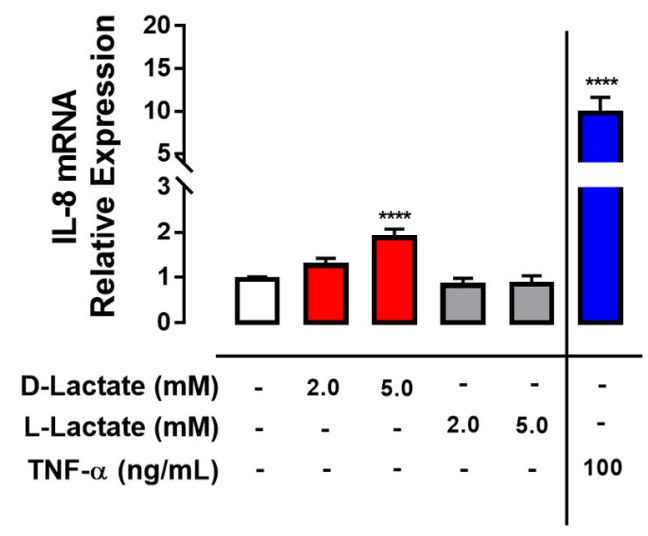

Figure 1. D-lactate increases the expression of IL-6 and IL-8 in bovine fibroblast like synoviocytes (bFLSs). Relative expression of IL-6 (A) and IL-8 (B) mRNA in bFLS cells treated with D-lactate or L-lactate for $6 \mathrm{~h}$. Bovine tumoral necrosis factor alpha (bTNF- $\alpha$ ) was used as a positive control. Each bar represents the mean \pm standard error of media (SEM). $n=5,{ }^{*} p<0.05 ;{ }^{* * * *} p<0.0001$ compared to control. 


\subsection{D-Lactate Uptake is Mediated by MCT1}

We observed an increase in the expression of IL-8 and IL-6 with D-lactate in bFLSs. Therefore, we hypothesized that bFLSs can express monocarboxylate transporters (MCTs) that mediate its bidirectional cotransport coupled to protons $\left(\mathrm{H}^{+}\right)$[40]. We observed that the mRNA of MCT1 and MCT4 were expressed, but MCT2 and MCT3 were not detected, in bFLSs (Figure 2A). Additionally, the relative abundances of MCT1 and MCT4 were different, and MCT1 was significantly more abundant than MCT4 (15-fold) (Figure 2A). In addition, the presence of MCT1 and MCT4 in bFLSs was corroborated by western blot (Figure 2B). Next, we evaluated the functionality of MCT1 in bFLSs. The influx of D-lactate in bFLSs was measured by assaying the intracellular contents of the enantiomers by HPLC. The stimulation of bFLSs with $5 \mathrm{mM}$ D-lactate for 5 min increased the intracellular concentration of D-lactate in comparison with cells treated with the vehicle alone (water) (Figure 2C). Additionally, the uptake of D-lactate was reduced by pretreatment of bFLSs with Ar-c155858 [41], which is a potent inhibitor of MCT1 and MCT2, and SR13800, which is a selective inhibitor of MCT1(Figure 2C) [42].
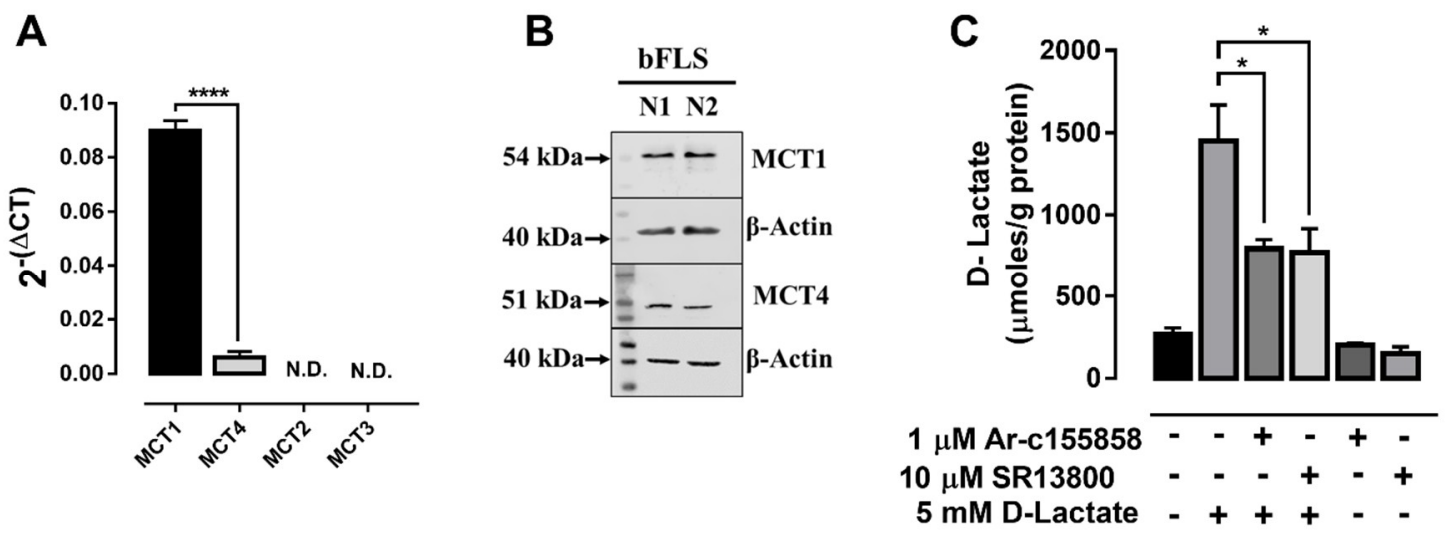

Figure 2. The uptake of D-lactate is mediated by monocarboxylate transporter 1 (MCT1). (A) The relative mRNA levels of MCT1, MCT2, MCT3 and MCT4 in bFLSs were normalized by S9 ribonucleoprotein (RPS9, housekeeping gene). (B) To confirm the presence of MCTs, immunoblotting of MCT1 and MCT4 in total bFLS proteins was performed. $\beta$-actin was used as a load control. (C) Intracellular levels of D-lactate in bFLSs stimulated for 5 min were measured by HPLC. In addition, two MCT1 inhibitors were used to confirm the transport of D-lactate, Ar-c155858 and SR13800, $n=5,{ }^{*} p<0.05$; **** $p<0.0001$.

\subsection{Inhibition of MCT1 Reduced the Expression of IL-6 and IL-8 Induced by D-Lactate}

The role of MCT1 in IL-8 and IL-6 expression induced by D-lactate was assessed. bFLSs were incubated with $1 \mu \mathrm{M}$ Ar-c155858 (inhibitor of MCT1 and MCT2) and then stimulated with $5 \mathrm{mM}$ D-lactate. Cotreatment with this inhibitor resulted in a significant reduction in the mRNA levels of IL-6 and IL-8 in comparison to D-lactate treatment alone (Figure 3A,C). Additionally, we observed a decrease in the secretion of both cytokines by ELISA (Figure 3B,D). To confirm the specificity of this inhibition, we evaluated the effect of Ar-c155858 on the expression of IL- 6 and IL- 8 induced by bTNF- $\alpha$. The treatment of bFLSs with Ar-c155858 did not change the expression and synthesis of both cytokines induced by bTNF- $\alpha$ (Figure 3A-D). 
A

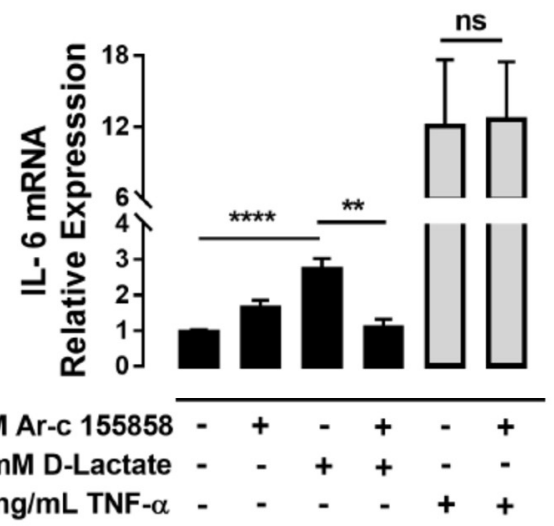

C

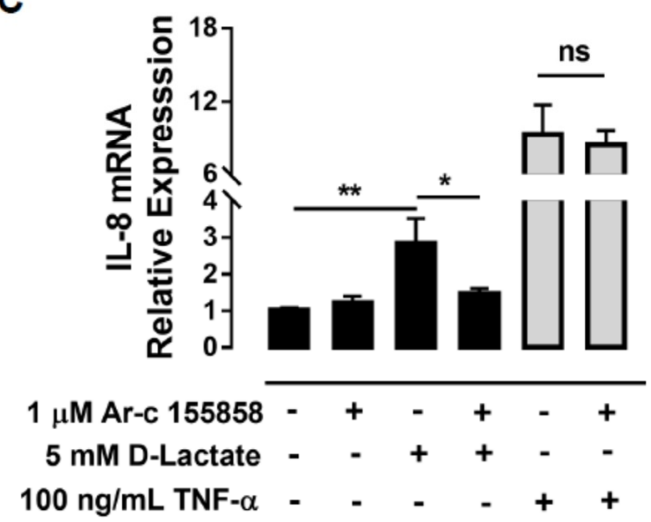

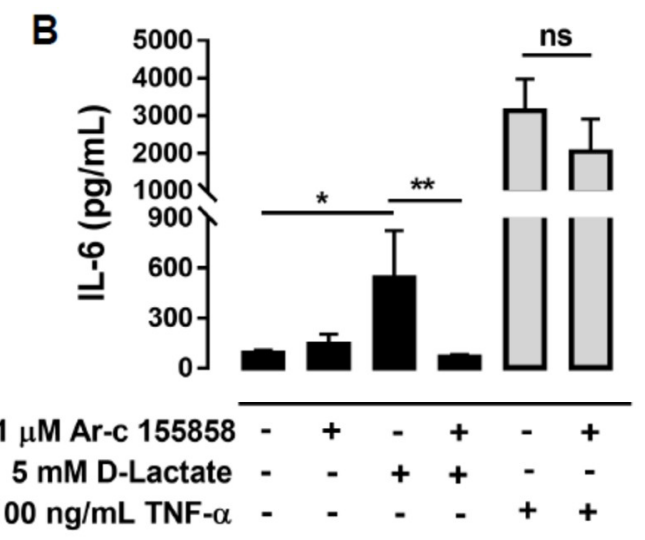

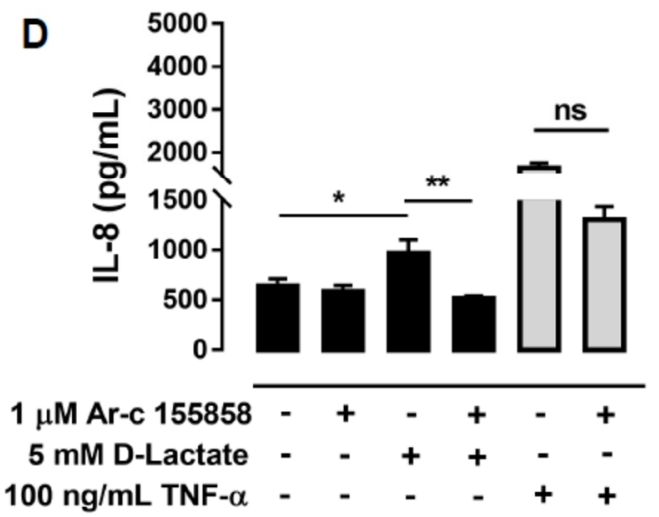

Figure 3. The influx of D-lactate by MCT1 increases the expression of IL-6 and IL-8. $(A, C)$ The relative mRNA levels of IL-6 and IL-8 in bFLSs pretreated with Ar-c 155858 and then stimulated with D-lactate or bTNF- $\alpha$ were normalized by S9 ribonucleoprotein (housekeeping gene). (B,D) The IL- 6 and IL-8 concentrations in the supernatants of bFLSs treated with Ar-c 155858 and stimulated with D-lactate or bTNF- $\alpha$ were measured by ELISA. The mean \pm SEM of five independent experiments is shown. NS: not significant. ${ }^{*} p<0.05,{ }^{* *} p<0.01,{ }^{* * * *} p<0.0001$ compared with control or D-lactate-treated cells.

\subsection{ERK1/2, p38 MAPK and PI3K/Akt Signaling Pathways Mediate IL-6 and IL-8 Production Induced by D-Lactate}

To investigate the cytoplasmic signaling involved in the regulation of IL- 6 and IL-8 mediated by D-lactate in bFLSs, we evaluated the phosphorylation of ERK1/2, p38 and Akt. Compared with the control, we observed that stimulation of bFLSs with $5 \mathrm{mM}$ D-lactate resulted in increases in the phosphorylation of these proteins, which peaked at $5 \mathrm{~min}$ of stimulation in all cases (Figure 4 and Supplementary Figure S4). In addition, bTNF- $\alpha$ was used as a control for phosphorylation. To determine whether these kinases are involved in the increase in IL- 6 and IL-8 expression induced by D-lactate, the pharmacologic inhibitors UO126, SB203580 or LY294002 were used. According to the results, the D-lactate-induced elevation in the IL- 6 and IL- 8 mRNA and protein levels were decreased by UO126, an inhibitor of MEK1/2 kinases whose function is to phosphorylate ERK1/2 (Figure 5A-D). Additionally, the inhibitor of p38 (SB203580) and the PI3K/Akt inhibitor (LY294002) reduced the expression and secretion of IL-6 and IL-8 (Figure 5A-D). Overall, our results suggest that D-lactate increases the expression and secretion of IL-6 and IL-8 in a manner that depends on the activation of the ERK1/2, p38 and Akt pathways. 

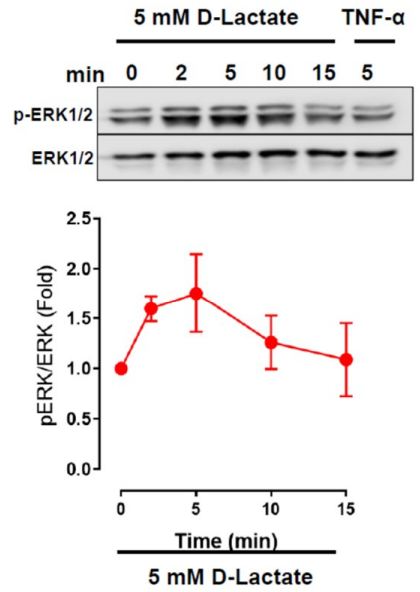
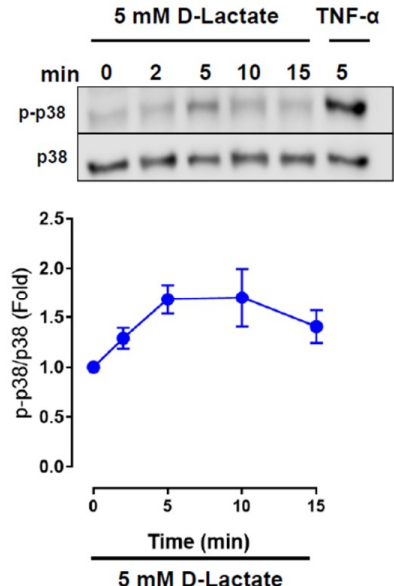
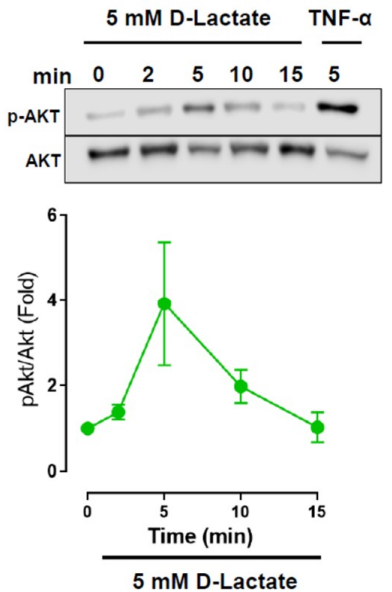

Figure 4. D-lactate increases the phosphorylation of ERK1/2, p38 and Akt in bFLSs. bFLSs were treated with $5 \mathrm{mM}$ D-lactate at a range of time points $(0,2,5,10$ and $15 \mathrm{~min})$. Total protein was analyzed by sodium dodecyl sulfate polyacrylamide gel electrophoresis (SDS/PAGE) and immunoblotting using specific antibodies against the phosphorylated forms of ERK1/2, p38 and Akt. Total ERK1/2, p38 and Akt were also evaluated by western blot for comparison. The images of one representative experiment are shown. The densitometry ratios of phospho extracellular signal-regulated kinase/extracellular-regulated kinase (pERK/ERK), p-p38/p38 and p-Akt/Akt are shown in the graphs $(n=3)$.

A

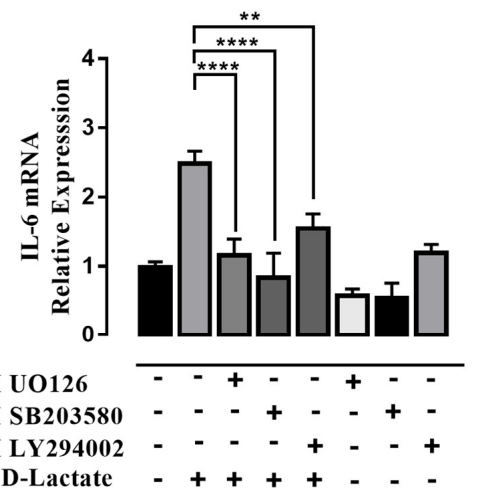

C

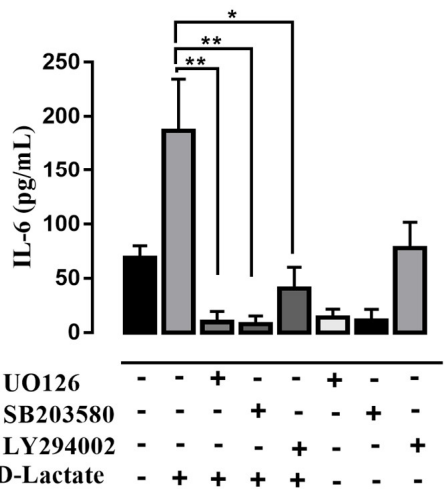

B
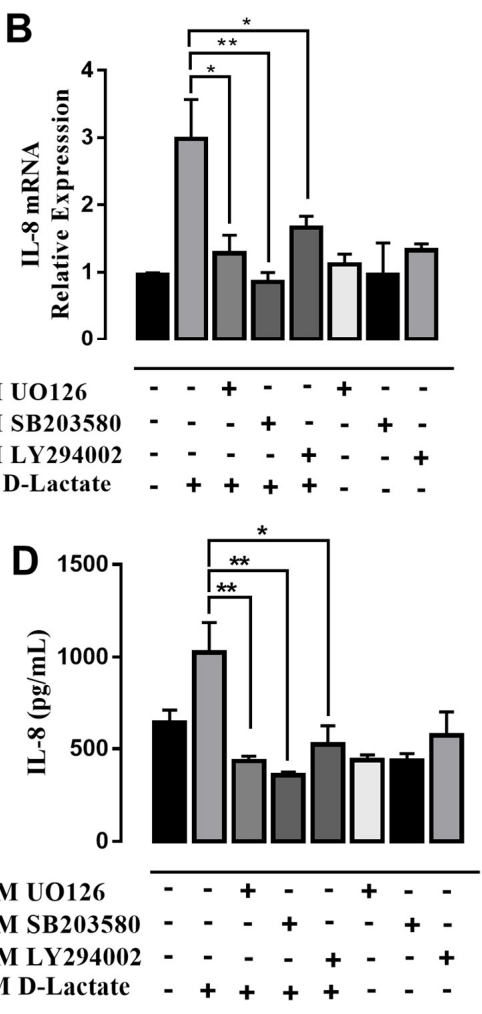

Figure 5. ERK1/2, p38 and Akt participate in the increase in IL- 6 and IL- 8 induced by D-lactate in bFLSs.(A,B) The relative mRNA levels of IL-6 and IL-8 in cells treated with UO126, SB203580 and LY294002 and then stimulated with D-lactate, normalized by S9 ribonucleoprotein (housekeeping gene), are shown. (C,D) The IL-6 and IL-8 concentrations in the supernatants of bFLSs treated with UO126, SB203580 and LY294002 and stimulated with D-lactate were measured by ELISA. The mean \pm SEM of five independent experiments is shown. ${ }^{*} p<0.05,{ }^{* *} p<0.01$, ${ }^{* * * *} p<0.0001$, compared with control or D-lactate-treated cells. 


\subsection{The Expression of IL-6 and IL-8 Induced by D-Lactate Is Dependent on NF- $\kappa B$ Activation}

We observed that D-lactate significantly induced the degradation of $\mathrm{I} \kappa \mathrm{B} \alpha$ after 30 min of stimulation (Figure 6A). bTNF- $\alpha$ was used as a positive control, and according to our experiments, we observed that bTNF- $\alpha$ induced the degradation of I $\mathrm{B} \alpha \alpha$ at $15 \mathrm{~min}$ (Figure $6 \mathrm{~B}$ ). Next, we evaluated the effect of BAY 11-7082, which irreversibly inhibits IKK $\alpha$ and thus reduced the phosphorylation and degradation of $I \kappa B \alpha$, resulting in the inactivation of NF- $\kappa B$ [43]. We observed a significant decrease in the expression and secretion of both cytokines induced by D-lactate (Figure 6C-F). Similarly, we observed that the expression and secretion of these cytokines induced by bTNF- $\alpha$ diminished significantly when the cells were pretreated with BAY 11-7082 (Figure 6C-F).

A
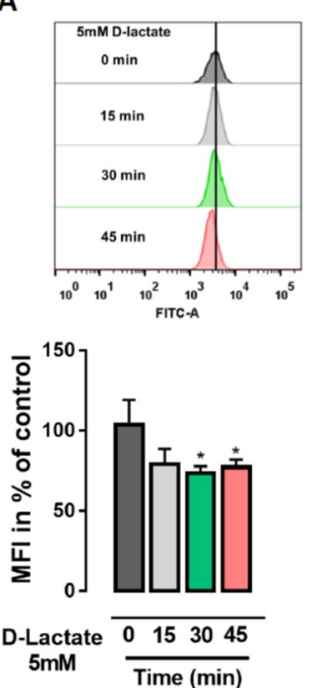

B
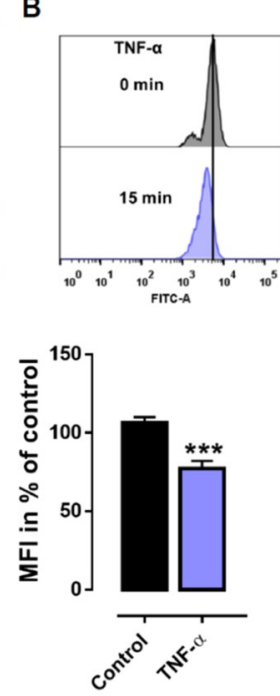

C

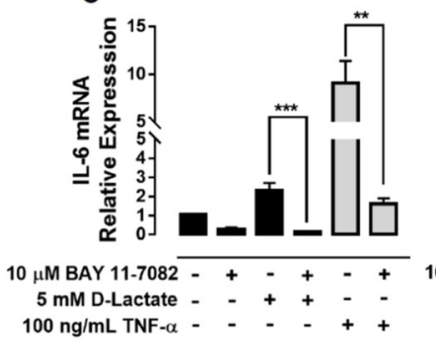

E

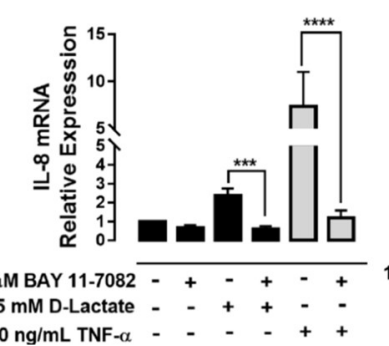

D

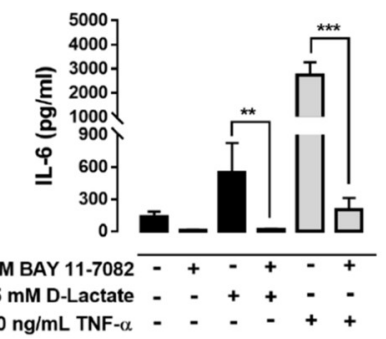

F

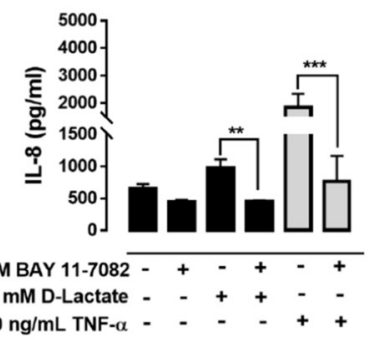

Figure 6. NF- $\mathrm{kB}$ regulates the increase in the expression and secretion of IL-6 and IL-8 induced by D-lactate in bFLSs. I $\kappa$ B $\alpha$ degradation was evaluated in cells treated with (A) D-lactate and (B) bTNF- $\alpha$ by flow cytometry. The cells were treated with BAY 11-7082, an NF-kB inhibitor, and then treated with D-lactate or bTNF- $\alpha$. (C,E) The mRNA levels of IL-6 and IL-8 normalized by RPS9 in cells treated with D-lactate or bTNF- $\alpha$ are shown. (D,F) The concentrations of IL-6 and IL-8 in cells treated with D-lactate or bTNF- $\alpha$ are shown. The mean \pm standard error of media (SEM) of five independent experiments is shown. ${ }^{*} p<0.05,{ }^{* *} p<0.01{ }^{* * *} p<0.001$; ${ }^{* * *} p<0.0001$ compared with control or D-lactate-treated cells.

\section{Discussion}

Bovines with ARA develop different clinical signs, such as ruminitis, polioencephalomalacia (calves), liver abscess and lameness [5,44,45]. In particular, lameness in cattle with ARA is closely associated with the presence of laminitis and aseptic neutrophilic polysynovitis [5,11,46-48]. However, despite decades of research on bovine lameness as a consequence of ruminal acidosis, the etiology and pathogenesis remain elusive [2,47,49,50]. During ARA, an increase in lactate in the ruminal fluid and plasma is observed [51]. Moreover, Morrow et al. (1973) were successful in experimentally inducing laminitis in lambs by intraruminal injection of lactic acid [52], suggesting that lactate could be involved in cattle lameness. Recently, several metabolic changes in the synovial fluid of cows with ARA and polysynovitis have been described, including an increases in L-lactate, D-lactate, and fructose and decreases in citric acid and threonine; moreover, the presence of D-lactate in the joint could contribute to the onset of synovitis in cattle [8,9]. In support of this, a proinflammatory effect of D-lactate has been described in neutrophils [21,53]; however, the effects of D-lactate on synovial tissue have not yet been described. 
We demonstrated that D-lactate increases the expression and release of IL-6 and IL-8 in bFLSs. IL-6 activates the immune system, favoring the inflammatory response, and in the joint, IL-6 expression correlates positively with the intensity of the lesions observed in aseptic joint diseases, such as rheumatoid arthritis (RA) [54-56]. In accordance with this, we previously demonstrated that D-lactate and IL-6 exhibit early increases in the synovial fluid of heifers with ARA and are increased before joint neutrophil recruitment [8]. Thus, IL-6 is considered a key player in joint inflammatory diseases $[56,57]$. In addition, FLSs may also interact with endothelial cells to promote neutrophil recruitment, which is inhibited by antibodies against IL-6, suggesting that the IL-6 produced by FLSs may increase the expression of adhesion molecules and chemokines by endothelial cells, facilitating neutrophil adherence [58].

IL-8 is a chemoattractant cytokine essential in neutrophil-mediated inflammation [59-64]. IL-8 increases the expression of CD11b in bovine neutrophils, promoting their migration to inflamed tissues $[65,66]$. In the synovial fluid of RA patients, IL-8 promotes leukocyte infiltration, and these leukocytes, once activated, release a variety of proteinases and enzymes, such as collagenase, elastase, myeloperoxidase and MMP-9, thus contributing to joint damage $[67,68]$. Previously, we observed an increase in the infiltration of neutrophils and MMP-9 in the synovial fluid of cows with ARA [8]; however, in the synovial fluid of animals with ARA, the presence of IL-8 has not yet been detected. We demonstrate that bTNF- $\alpha$, a well-known joint proinflammatory agent [12,69-71], increases the production of IL- 6 and IL-8 in bFLSs in a similar fashion to that described in hFLSs [72]. bTNF- $\alpha$, but not D-lactate, increased the expression of CXCL-1 and CXCL-2. In this context, our results suggest that D-lactate could play a key role in the polysynovitis observed during ARA through the synthesis of IL-6 and IL- 8 by bFLS.

Both stereoisomers, L-lactate and D-lactate, can exert several proinflammatory effects [18,73], including NET formation [21,73]. In synovial fluid induced by ARA, the presence of NET has been reported [8]. D-lactate induces NET formation and dependent of its uptake via MCT-1, in bovine neutrophils. [21]. In addition, IL-8 and IL-6 have been described as NET inducers [74,75] and therefore, we did not discard that the release of these cytokines induced by D-lactate contributes to NET release observed during synovitis in cattle with ARA [8]. L-lactate increases the production of IL-8 in human endothelial cells [76] and IL-6 in human skeletal muscle cells [77]. Moreover, it has been proposed that the IL- 6 and IL-8 production induced by TNF- $\alpha$ in RA-FLSs is dependent on L-lactate [18]. Surprisingly, we observed that L-lactate did not induce an increase in the production of proinflammatory cytokines in bFLSs. Other authors showed that D-lactate more strongly regulates the differentiation of mouse adipocytes compared to L-lactate [78], suggesting that D- and L-lactate can exert different effects based on the cellular type used. Furthermore, our results exclude a possible proinflammatory effect that has been attributed to $\mathrm{pH}$, since the $\mathrm{pKa}$ of both enantiomers is $3.86[3,79]$.

At physiological $\mathrm{pH}$, both enantiomers are dissociated with a ratio of 3000:1 for lactate ions and lactic acid [3]. Lactate is transported into and out of cells via proton-dependent monocarboxylate transporters (MCTs) [3,80]. Some isoforms of MCTs have been described in bovine rumen epithelium [81] and bovine neutrophils [21]. In this research, we identified a higher expression of MCT1 compared with MCT4 in bFLSs. In contrast, RA-FLSs exhibit higher levels of MCT4 than MCT1, and similar expression levels are observed in osteoarthritis FLSs [82]. We demonstrated that D-lactate can be transported by bFLSs via MCT1. In addition, MCT1 inhibition blocked the expression and secretion of IL-6 and IL-8 induced by D-lactate. Hence, the current study provides the first evidence that MCT1 is involved in D-lactate entry in bFLSs, which is required for proinflammatory cytokine expression. In accordance with the above, it has been shown that endothelial cells can uptake lactate by MCT1, allowing the production of IL-8 [76]. Other authors demonstrated that the uptake of lactate through the MCT1 transporter increased COX-2 expression in monocytes [83] and regulated the migration of $\mathrm{CD} 8^{+} \mathrm{T}$ cells [53]. Moreover, inhibition of D-lactate influx reduced the NET release and endothelial adhesion induced by D-lactate in bovines [21]. 
We observed that D-lactate increased the phosphorylation of ERK1/2 and p38, in bFLSs, being these proteins pertaining to the MAPK family. Other authors have suggested that lactate could activate ERK1/2 and p38 MAPK in RA-FLSs [18]. Therefore, our results are the first to show that D-lactate activates the MAPK signaling pathway in bFLSs. In addition, the inhibition of these kinases decreased IL-6 and IL-8 expression. p38 MAPK and ERK1/2 regulate the synthesis of IL-6, IL-12, IL-23 and TNF- $\alpha$ in RA-FLSs [84-86]. MAPKs play important roles in mediating synovial inflammation and joint destruction, and they are considered critical molecular targets for therapeutic intervention in joint inflammation $[18,87]$.

Our results also suggest that D-lactate and bTNF- $\alpha$ activate the PI3K/Akt pathway in bFLSs. Moreover, the inhibition of PI3K/Akt reduced the expression and secretion of IL- 6 and IL-8 induced by D-lactate. Similarly, other authors have described that TNF- $\alpha$ can induce the expression of IL- 6 and IL-8 via PI3K/Akt in human FLSs [30,70].

The ERK1/2, p38 and PI3K/Akt pathways regulate the nuclear translocation of NF-kB, which is essential in proinflammatory cytokines production in human FLSs [88-92]. In connection with this, NF- $\mathrm{KB}$ binding sites in the promoter region of the IL- 6 and IL-8 genes in RA synovial tissue have been previously reported [93]. Thus, we tested the ability of D-lactate to induce cytokine expression via the NF- $\mathrm{kB}$ pathway. Our experiments demonstrated that D-lactate and bTNF- $\alpha$ increase the degradation of I $\mathrm{K} B \alpha$ in bFLSs. Moreover, the pharmacological inhibition of NF- $k B$ reduced the expression of IL- 8 and IL- 6 induced by D-lactate and bTNF- $\alpha$. Other authors have shown that lactate increases the degradation of $I \kappa B \alpha$, promoting the translocation of NF- $\kappa B$ to the nucleus in human FLSs and endothelial cells [18,76]. In human FLSs, TNF- $\alpha$ induces the phosphorylation and degradation of $I \kappa B \alpha[94]$, permitting NF- $\kappa B$ translocation into the nucleus to activate the transcription of target genes [43]. Additionally, Georganas et al. demonstrated that the activation of NF- $\mathrm{KB}$ is key for the constitutive secretion of IL- 6 and IL- 8 as well as the secretion of these cytokines induced by IL-1 $\beta$ in RA-FLSs [95]. Altogether, our results strongly suggest that D-lactate increases the release of pro-inflammatory cytokines, activating intracellular signaling pathways in bovine synoviocytes, supporting the role of D-lactate in the onset of synovitis in cattle with ARA.

A dairy herd with ruminal acidosis showed higher ruminal D-lactic acid production associated with an increase in swollen fetlocks and laminitis [96]. Similarly, other authors observed arthritis in cattle that was defined as "laminitis with concurrent general affection", in addition, the total contents of protein and leukocytes was increased in the synovial fluid from fetlock joints [97]. Furthermore, ARA induced experimentally in cattle produces aseptic synovitis and lameness [1,8]. Our results contribute to propose D-lactate as a metabolic pro-inflammatory agent for the joint of cattle. However, in vivo experiments are required to demonstrate the role of D-lactate in bovine lameness.

\section{Conclusions}

The present study revealed that in bFLSs the influx of D-lactate, through MCT1, induces the ERK1/2, p38, Akt, and NF-kB signaling pathways that promote the expression and secretion of IL-6 and IL-8.

Supplementary Materials: The following are available online at http://www.mdpi.com/2076-2615/10/11/2105/s1, Figure S1. Expression of Vimentin and CD14 in bFLSs and neutrophils, respectively. (A) To confirm the isolation of bFLS, the marker vimentin was used, and the expression of vimentin was compared with that of a commercial line of bFLS. (B) The absence of CD14 is an FLS marker, and bovine neutrophils (bPMNs) were used as a positive control. Figure S2. Expression of proinflammatory cytokines in bFLS. Relative expression of CXCL-1, CXCL-2, CXCL-3 and CXCL-6 mRNA in bFLSs treated with D-lactate, L-lactate or bTNF- $\alpha$ for 6 h. ${ }^{* *} p<0.01$; ${ }^{* * *} p<0.001$ compared with the control. Figure S3. Na ${ }^{+}$D-lactate increases the expression of IL- 6 and IL-8 in bFLSs. Relative expression of IL- 6 and IL- 8 mRNA in bFLS cells treated with $\mathrm{Na}^{+}$D-lactate for $6 \mathrm{~h}$. Each bar represents the average \pm S.E.M. $n=5 .{ }^{*} p<0.05$ compared to the control. Figure S4. D-lactate increases the phosphorylation of ERK1/2, p38 and Akt in bFLSs. bFLSs were treated with $5 \mathrm{mM}$ D-lactate during $5 \mathrm{~min}$. Total protein was analyzed by SDS/PAGE and immunoblotting using specific antibodies against the phosphorylated forms of ERK1/2, p38 and Akt. Total ERK1/2, p38 and Akt were also evaluated by western blot for comparison. TNF- $\alpha(100 \mathrm{ng} / \mathrm{mL})$ was used as a positive control. The images of one representative experiment are shown. 
Author Contributions: Conceptualization, R.A.B.; data curation, G.M.G.; formal analysis, C.M., J.Q., M.A.H. and R.A.B.; investigation, C.M., J.Q., S.T., S.C., M.D.C. and P.A.; methodology, R.A.B.; project administration, R.A.B.; writing-original draft, C.M., M.A.H. and R.A.B.; writing-review \& editing, R.A.B. All authors have read and agreed to the published version of the manuscript.

Funding: This work was supported by Fondo Nacional de Desarrollo Científico y Tecnológico (Grant FONDECYT No: 1180946). This work was supported by Scholarship “Comisión Nacional de Investigación Científica y Tecnológica (CONICYT) Doctorado Nacional-Doctorado 2017" (Folio number 21171843).

Conflicts of Interest: The authors declare no conflict of interest with respect to the research, authorship, and/or publication of this article.

\section{References}

1. Danscher, A.M.; Enemark, H.L.; Andersen, P.H.; Aalbaek, B.; Nielsen, O.L. Polysynovitis after oligofructose overload in dairy cattle. J. Comp. Pathol. 2010, 142, 129-138. [CrossRef] [PubMed]

2. Hernandez, J.; Benedito, J.L.; Abuelo, A.; Castillo, C. Ruminal acidosis in feedlot: From aetiology to prevention. Sci. World J. 2014, 2014, 702572. [CrossRef] [PubMed]

3. Ewaschuk, J.B.; Naylor, J.M.; Zello, G.A. D-lactate in human and ruminant metabolism. J. Nutr. 2005, 135, 1619-1625. [CrossRef] [PubMed]

4. Kalapos, M.P. Methylglyoxal in living organisms: Chemistry, biochemistry, toxicology and biological implications. Toxicol. Lett. 1999, 110, 145-175. [CrossRef]

5. Owens, F.N.; Secrist, D.S.; Hill, W.J.; Gill, D.R. Acidosis in cattle: A review. J. Anim. Sci. 1998, 76, $275-286$. [CrossRef]

6. Nagaraja, T.G.; Titgemeyer, E.C. Ruminal acidosis in beef cattle: The current microbiological and nutritional outlook. J. Dairy Sci. 2007, 90 (Suppl. 1), E17-E38. [CrossRef]

7. Harmon, D.L.; Britton, R.A.; Prior, R.L.; Stock, R.A. Net portal absorption of lactate and volatile fatty acids in steers experiencing glucose-induced acidosis or fed a 70\% concentrate diet ad libitum. J. Anim. Sci. 1985, 60, 560-569. [CrossRef]

8. Hidalgo, A.I.; Carretta, M.D.; Alarcon, P.; Manosalva, C.; Muller, A.; Navarro, M.; Hidalgo, M.A.; Kaehne, T.; Taubert, A.; Hermosilla, C.R.; et al. Pro-inflammatory mediators and neutrophils are increased in synovial fluid from heifers with acute ruminal acidosis. BMC Vet. Res. 2019, 15, 225. [CrossRef]

9. Alarcon, P.; Hidalgo, A.I.; Manosalva, C.; Cristi, R.; Teuber, S.; Hidalgo, M.A.; Burgos, R.A. Metabolic disturbances in synovial fluid are involved in the onset of synovitis in heifers with acute ruminal acidosis. Sci. Rep. 2019, 9, 5452. [CrossRef]

10. Abeysekara, S.; Naylor, J.M.; Wassef, A.W.; Isak, U.; Zello, G.A. D-Lactic acid-induced neurotoxicity in a calf model. Am. J. Physiol. Endocrinol. Metab. 2007, 293, E558-E565. [CrossRef]

11. Danscher, A.M.; Enemark, J.M.; Telezhenko, E.; Capion, N.; Ekstrom, C.T.; Thoefner, M.B. Oligofructose overload induces lameness in cattle. J. Dairy Sci. 2009, 92, 607-616. [CrossRef] [PubMed]

12. Bartok, B.; Firestein, G.S. Fibroblast-like synoviocytes: Key effector cells in rheumatoid arthritis. Immunol. Rev. 2010, 233, 233-255. [CrossRef] [PubMed]

13. Bottini, N.; Firestein, G.S. Duality of fibroblast-like synoviocytes in RA: Passive responders and imprinted aggressors. Nat. Rev. Rheumatol. 2013, 9, 24-33. [CrossRef] [PubMed]

14. Turner, J.D.; Filer, A. The role of the synovial fibroblast in rheumatoid arthritis pathogenesis. Curr. Opin. Rheumatol. 2015, 27, 175-182. [CrossRef] [PubMed]

15. Harris, E.D., Jr. Rheumatoid arthritis. Pathophysiology and implications for therapy. N. Engl. J. Med. 1990, 322, 1277-1289. [CrossRef]

16. Tolboom, T.C.; van der Helm-Van Mil, A.H.; Nelissen, R.G.; Breedveld, F.C.; Toes, R.E.; Huizinga, T.W. Invasiveness of fibroblast-like synoviocytes is an individual patient characteristic associated with the rate of joint destruction in patients with rheumatoid arthritis. Arthritis Rheum. 2005, 52, 1999-2002. [CrossRef]

17. De Oliveira, P.G.; Farinon, M.; Sanchez-Lopez, E.; Miyamoto, S.; Guma, M. Fibroblast-Like Synoviocytes Glucose Metabolism as a Therapeutic Target in Rheumatoid Arthritis. Front. Immunol. 2019, 10, 1743. [CrossRef]

18. Zou, Y.; Zeng, S.; Huang, M.; Qiu, Q.; Xiao, Y.; Shi, M.; Zhan, Z.; Liang, L.; Yang, X.; Xu, H. Inhibition of 6-phosphofructo-2-kinase suppresses fibroblast-like synoviocytes-mediated synovial inflammation and joint destruction in rheumatoid arthritis. Br. J. Pharm. 2017, 174, 893-908. [CrossRef] 
19. Bakker, J.; Schieveld, S.J.; Brinkert, W. [Serum lactate level as a indicator of tissue hypoxia in severely ill patients]. Ned. Tijdschr. Geneeskd. 2000, 144, 737-741.

20. Verma, I.; Kaur, S.; Goyal, S.; Goyal, S.; Multani, J.S.; Narang, A.P. Diagnostic value of lactate levels in acute abdomen disorders. Indian J. Clin. Biochem. 2014, 29, 382-385. [CrossRef]

21. Alarcon, P.; Manosalva, C.; Conejeros, I.; Carretta, M.D.; Munoz-Caro, T.; Silva, L.M.R.; Taubert, A.; Hermosilla, C.; Hidalgo, M.A.; Burgos, R.A. d(-) Lactic Acid-Induced Adhesion of Bovine Neutrophils onto Endothelial Cells Is Dependent on Neutrophils Extracellular Traps Formation and CD11b Expression. Front. Immunol. 2017, 8, 975. [CrossRef] [PubMed]

22. Ding, J.; Li, S.; Jiang, L.; Li, Y.; Zhang, X.; Song, Q.; Hayat, M.A.; Zhang, J.T.; Wang, H. Laminar Inflammation Responses in the Oligofructose Overload Induced Model of Bovine Laminitis. Front. Vet. Sci. 2020, 7, 351. [CrossRef] [PubMed]

23. Thoefner, M.B.; Wattle, O.; Pollitt, C.C.; French, K.R.; Nielsen, S.S. Histopathology of oligofructose-induced acute laminitis in heifers. J. Dairy Sci. 2005, 88, 2774-2782. [CrossRef] [PubMed]

24. Neuenschwander, H.M.; Moreira, J.J.; Vendruscolo, C.P.; Fulber, J.; Seidel, S.R.T.; Michelacci, Y.M.; Baccarin, R.Y.A. Hyaluronic acid has chondroprotective and joint-preserving effects on LPS-induced synovitis in horses. J. Vet. Sci. 2019, 20, e67. [CrossRef]

25. Berenbaum, F. Signaling transduction: Target in osteoarthritis. Curr. Opin. Rheumatol. 2004, 16, 616-622. [CrossRef]

26. Yamanishi, Y.; Firestein, G.S. Pathogenesis of rheumatoid arthritis: The role of synoviocytes. Rheum. Dis. Clin. N. Am. 2001, 27, 355-371. [CrossRef]

27. Akhtar, M.; Guo, S.; Guo, Y.F.; Zahoor, A.; Shaukat, A.; Chen, Y.; Umar, T.; Deng, P.G.; Guo, M. Upregulated-gene expression of pro-inflammatory cytokines (TNF-alpha, IL-1beta and IL-6) via TLRs following NF-kappaB and MAPKs in bovine mastitis. Acta Trop. 2020, 207, 105458. [CrossRef]

28. Ray, A.; Ray, B.K. Lipopolysaccharide-mediated induction of the bovine interleukin- 6 gene in monocytes requires both NF-kappa B and C/EBP binding sites. DNA Cell Biol. 1995, 14, 795-802. [CrossRef]

29. Fitzgerald, D.C.; Meade, K.G.; McEvoy, A.N.; Lillis, L.; Murphy, E.P.; MacHugh, D.E.; Baird, A.W. Tumour necrosis factor-alpha (TNF-alpha) increases nuclear factor kappaB (NFkappaB) activity in and interleukin-8 (IL-8) release from bovine mammary epithelial cells. Vet. Immunol. Immunopathol. 2007, 116, 59-68. [CrossRef]

30. Jia, Q.; Cheng, W.; Yue, Y.; Hu, Y.; Zhang, J.; Pan, X.; Xu, Z.; Zhang, P. Cucurbitacin E inhibits TNF-alpha-induced inflammatory cytokine production in human synoviocyte MH7A cells via suppression of PI3K/Akt/NF-kappaB pathways. Int. Immunopharmacol. 2015, 29, 884-890. [CrossRef]

31. Li, Y.; Li, P.; Lin, S.H.; Zheng, Y.Q.; Zheng, X.X. Paeonol inhibited TNFalpha-induced GM-CSF expression in fibroblast-like synoviocytes. Int. J. Clin. Pharm. Ther. 2014, 52, 986-996. [CrossRef] [PubMed]

32. Varani, K.; De Mattei, M.; Vincenzi, F.; Gessi, S.; Merighi, S.; Pellati, A.; Ongaro, A.; Caruso, A.; Cadossi, R.; Borea, P.A. Characterization of adenosine receptors in bovine chondrocytes and fibroblast-like synoviocytes exposed to low frequency low energy pulsed electromagnetic fields. Osteoarthr. Cartil. 2008, 16, 292-304. [CrossRef] [PubMed]

33. Sappino, A.P.; Schurch, W.; Gabbiani, G. Differentiation repertoire of fibroblastic cells: Expression of cytoskeletal proteins as marker of phenotypic modulations. Lab. Investig. 1990, 63, 144-161. [PubMed]

34. Mena, J.; Manosalva, C.; Ramirez, R.; Chandia, L.; Carroza, D.; Loaiza, A.; Burgos, R.A.; Hidalgo, M.A. Linoleic acid increases adhesion, chemotaxis, granule release, intracellular calcium mobilisation, MAPK phosphorylation and gene expression in bovine neutrophils. Vet. Immunol. Immunopathol. 2013, 151, 275-284. [CrossRef]

35. Hidalgo, M.A.; Ojeda, F.; Eyre, P.; LaBranche, T.P.; Smith, C.; Hancke, J.L.; Burgos, R.A. Platelet-activating factor increases $\mathrm{pH}(\mathrm{i})$ in bovine neutrophils through the PI3K-ERK1/2 pathway. Br. J. Pharm. 2004, 141, 311-321. [CrossRef]

36. Favata, M.F.; Horiuchi, K.Y.; Manos, E.J.; Daulerio, A.J.; Stradley, D.A.; Feeser, W.S.; Van Dyk, D.E.; Pitts, W.J.; Earl, R.A.; Hobbs, F.; et al. Identification of a novel inhibitor of mitogen-activated protein kinase kinase. J. Biol. Chem. 1998, 273, 18623-18632. [CrossRef]

37. Pierce, J.W.; Schoenleber, R.; Jesmok, G.; Best, J.; Moore, S.A.; Collins, T.; Gerritsen, M.E. Novel inhibitors of cytokine-induced IkappaBalpha phosphorylation and endothelial cell adhesion molecule expression show anti-inflammatory effects in vivo. J. Biol. Chem. 1997, 272, 21096-21103. [CrossRef] [PubMed] 
38. Kumar, S.; Jiang, M.S.; Adams, J.L.; Lee, J.C. Pyridinylimidazole compound SB 203580 inhibits the activity but not the activation of p38 mitogen-activated protein kinase. Biochem. Biophys. Res. Commun. 1999, 263, 825-831. [CrossRef]

39. Livak, K.J.; Schmittgen, T.D. Analysis of relative gene expression data using real-time quantitative PCR and the 2(-Delta Delta C(T)) Method. Methods 2001, 25, 402-408. [CrossRef]

40. Halestrap, A.P. The monocarboxylate transporter family-Structure and functional characterization. IUBMB Life 2012, 64, 1-9. [CrossRef]

41. Ovens, M.J.; Davies, A.J.; Wilson, M.C.; Murray, C.M.; Halestrap, A.P. AR-C155858 is a potent inhibitor of monocarboxylate transporters MCT1 and MCT2 that binds to an intracellular site involving transmembrane helices 7-10. Biochem. J. 2010, 425, 523-530. [CrossRef] [PubMed]

42. Berrios, C.; Padi, M.; Keibler, M.A.; Park, D.E.; Molla, V.; Cheng, J.; Lee, S.M.; Stephanopoulos, G.; Quackenbush, J.; DeCaprio, J.A. Merkel Cell Polyomavirus Small T Antigen Promotes Pro-Glycolytic Metabolic Perturbations Required for Transformation. PLoS Pathog. 2016, 12, e1006020. [CrossRef] [PubMed]

43. Bhatt, D.; Ghosh, S. Regulation of the NF-kappaB-Mediated Transcription of Inflammatory Genes. Front. Immunol. 2014, 5, 71. [CrossRef] [PubMed]

44. Nagaraja, T.G.; Lechtenberg, K.F. Acidosis in feedlot cattle. Vet. Clin. N. Am.-Food Anim. Pr. 2007, 23, 333-350. [CrossRef]

45. Lorenz, I.; Gentile, A. D-lactic acidosis in neonatal ruminants. Vet. Clin. N. Am.-Food Anim. Pr. 2014, 30, 317-331. [CrossRef] [PubMed]

46. Dunlop, R.H.; Hammond, P.B. D-lactic acidosis of ruminants. Ann. N. Y. Acad. Sci. 1965, 119, 1109-1132. [CrossRef]

47. Danscher, A.M.; Toelboell, T.H.; Wattle, O. Biomechanics and histology of bovine claw suspensory tissue in early acute laminitis. J. Dairy Sci. 2010, 93, 53-62. [CrossRef]

48. Thoefner, M.B.; Pollitt, C.C.; Van Eps, A.W.; Milinovich, G.J.; Trott, D.J.; Wattle, O.; Andersen, P.H. Acute bovine laminitis: A new induction model using alimentary oligofructose overload. J. Dairy Sci. 2004, 87, 2932-2940. [CrossRef]

49. Mgasa, M.N. Bovine pododermatitis aseptica diffusa (laminitis) aetiology, pathogenesis, treatment and control. Vet. Res. Commun. 1987, 11, 235-241. [CrossRef]

50. Bailey, S.R.; Marr, C.M.; Elliott, J. Current research and theories on the pathogenesis of acute laminitis in the horse. Vet. J. 2004, 167, 129-142. [CrossRef]

51. Concha, C.; Carretta, M.D.; Alarcon, P.; Conejeros, I.; Gallardo, D.; Hidalgo, A.I.; Tadich, N.; Caceres, D.D.; Hidalgo, M.A.; Burgos, R.A. Oxidative response of neutrophils to platelet-activating factor is altered during acute ruminal acidosis induced by oligofructose in heifers. J. Vet. Sci. 2014, 15, 217-224. [CrossRef] [PubMed]

52. Morrow, L.L.; Tumbleson, M.E.; Kintner, L.D.; Pfander, W.H.; Preston, R.L. Laminitis in lambs injected with lactic acid. Am. J. Vet. Res. 1973, 34, 1305-1307. [PubMed]

53. Haas, R.; Smith, J.; Rocher-Ros, V.; Nadkarni, S.; Montero-Melendez, T.; D'Acquisto, F.; Bland, E.J.; Bombardieri, M.; Pitzalis, C.; Perretti, M.; et al. Lactate Regulates Metabolic and Pro-inflammatory Circuits in Control of T Cell Migration and Effector Functions. PLoS Biol. 2015, 13, e1002202. [CrossRef] [PubMed]

54. Kaneko, S.; Satoh, T.; Chiba, J.; Ju, C.; Inoue, K.; Kagawa, J. Interleukin-6 and interleukin-8 levels in serum and synovial fluid of patients with osteoarthritis. Cytokines Cell. Mol. Ther. 2000, 6, 71-79. [CrossRef] [PubMed]

55. Doss, F.; Menard, J.; Hauschild, M.; Kreutzer, H.J.; Mittlmeier, T.; Muller-Steinhardt, M.; Muller, B. Elevated IL-6 levels in the synovial fluid of osteoarthritis patients stem from plasma cells. Scand. J. Rheumatol. 2007, 36, 136-139. [CrossRef]

56. Narazaki, M.; Tanaka, T.; Kishimoto, T. The role and therapeutic targeting of IL-6 in rheumatoid arthritis. Expert Rev. Clin. Immunol. 2017, 13, 535-551. [CrossRef]

57. Hwang, S.Y.; Kim, J.Y.; Kim, K.W.; Park, M.K.; Moon, Y.; Kim, W.U.; Kim, H.Y. IL-17 induces production of IL-6 and IL-8 in rheumatoid arthritis synovial fibroblasts via NF-kappaB- and PI3-kinase/Akt-dependent pathways. Arthritis Res. Ther. 2004, 6, R120-R128. [CrossRef]

58. Lally, F.; Smith, E.; Filer, A.; Stone, M.A.; Shaw, J.S.; Nash, G.B.; Buckley, C.D.; Rainger, G.E. A novel mechanism of neutrophil recruitment in a coculture model of the rheumatoid synovium. Arthritis Rheum. 2005, 52, 3460-3469. [CrossRef]

59. Kobayashi, Y. The role of chemokines in neutrophil biology. Front. Biosci. 2008, 13, 2400-2407. [CrossRef] 
60. Szekanecz, Z.; Vegvari, A.; Szabo, Z.; Koch, A.E. Chemokines and chemokine receptors in arthritis. Front. Biosci. (Sch. Ed.) 2010, 2, 153-167. [CrossRef]

61. Rubbert, A.; Combadiere, C.; Ostrowski, M.; Arthos, J.; Dybul, M.; Machado, E.; Cohn, M.A.; Hoxie, J.A.; Murphy, P.M.; Fauci, A.S.; et al. Dendritic cells express multiple chemokine receptors used as coreceptors for HIV entry. J. Immunol. 1998, 160, 3933-3941. [PubMed]

62. Zhu, X.; Xiao, L.; Huo, R.; Zhang, J.; Lin, J.; Xie, J.; Sun, S.; He, Y.; Sun, Y.; Zhou, Z.; et al. Cyr61 is involved in neutrophil infiltration in joints by inducing IL-8 production by fibroblast-like synoviocytes in rheumatoid arthritis. Arthritis Res. Ther. 2013, 15, R187. [CrossRef] [PubMed]

63. Peichl, P.; Ceska, M.; Effenberger, F.; Haberhauer, G.; Broell, H.; Lindley, I.J. Presence of NAP-1/IL-8 in synovial fluids indicates a possible pathogenic role in rheumatoid arthritis. Scand. J. Immunol. 1991, 34, 333-339. [CrossRef] [PubMed]

64. Rampart, M.; Herman, A.G.; Grillet, B.; Opdenakker, G.; Van Damme, J. Development and application of a radioimmunoassay for interleukin-8: Detection of interleukin-8 in synovial fluids from patients with inflammatory joint disease. Lab. Investig. 1992, 66, 512-518.

65. McClenahan, D.; Fagliari, J.; Evanson, O.; Weiss, D. Role of inflammatory mediators in priming, activation, and deformability of bovine neutrophils. Am. J. Vet. Res. 2000, 61, 492-498. [CrossRef]

66. Zerbe, H.; Schuberth, H.J.; Engelke, F.; Frank, J.; Klug, E.; Leibold, W. Development and comparison of in vivo and in vitro models for endometritis in cows and mares. Theriogenology 2003, 60, 209-223. [CrossRef]

67. Valcamonica, E.; Chighizola, C.B.; Comi, D.; De Lucia, O.; Pisoni, L.; Murgo, A.; Salvi, V.; Sozzani, S.; Meroni, P.L. Levels of chemerin and interleukin 8 in the synovial fluid of patients with inflammatory arthritides and osteoarthritis. Clin. Exp. Rheumatol. 2014, 32, 243-250.

68. Kraan, M.C.; Patel, D.D.; Haringman, J.J.; Smith, M.D.; Weedon, H.; Ahern, M.J.; Breedveld, F.C.; Tak, P.P. The development of clinical signs of rheumatoid synovial inflammation is associated with increased synthesis of the chemokine CXCL8 (interleukin-8). Arthritis Res. 2001, 3, 65-71. [CrossRef]

69. Yu, F.Y.; Xie, C.Q.; Jiang, C.L.; Sun, J.T.; Huang, X.W. TNFalpha increases inflammatory factor expression in synovial fibroblasts through the tolllike receptor3mediated ERK/AKT signaling pathway in a mouse model of rheumatoid arthritis. Mol. Med. Rep. 2018, 17, 8475-8483. [CrossRef]

70. Li, H.; Xie, S.; Qi, Y.; Li, H.; Zhang, R.; Lian, Y. TNF-alpha increases the expression of inflammatory factors in synovial fibroblasts by inhibiting the PI3K/AKT pathway in a rat model of monosodium iodoacetate-induced osteoarthritis. Exp. Ther. Med. 2018, 16, 4737-4744. [CrossRef]

71. Matsuno, H.; Yudoh, K.; Katayama, R.; Nakazawa, F.; Uzuki, M.; Sawai, T.; Yonezawa, T.; Saeki, Y.; Panayi, G.S.; Pitzalis, C.; et al. The role of TNF-alpha in the pathogenesis of inflammation and joint destruction in rheumatoid arthritis (RA): A study using a human RA/SCID mouse chimera. Rheumatology 2002, 41, 329-337. [CrossRef] [PubMed]

72. Jiao, Z.; Wang, W.; Ma, J.; Wang, S.; Su, Z.; Xu, H. Notch signaling mediates TNF-alpha-induced IL-6 production in cultured fibroblast-like synoviocytes from rheumatoid arthritis. Clin. Dev. Immunol. 2012, 2012, 350209. [CrossRef] [PubMed]

73. Awasthi, D.; Nagarkoti, S.; Sadaf, S.; Chandra, T.; Kumar, S.; Dikshit, M. Glycolysis dependent lactate formation in neutrophils: A metabolic link between NOX-dependent and independent NETosis. Biochim. Biophys. Acta-Mol. Basis Dis. 2019, 1865, 165542. [CrossRef] [PubMed]

74. An, Z.; Li, J.; Yu, J.; Wang, X.; Gao, H.; Zhang, W.; Wei, Z.; Zhang, J.; Zhang, Y.; Zhao, J.; et al. Neutrophil extracellular traps induced by IL-8 aggravate atherosclerosis via activation NF-kappaB signaling in macrophages. Cell Cycle 2019, 18, 2928-2938. [CrossRef] [PubMed]

75. Joshi, M.B.; Lad, A.; Bharath Prasad, A.S.; Balakrishnan, A.; Ramachandra, L.; Satyamoorthy, K. High glucose modulates IL-6 mediated immune homeostasis through impeding neutrophil extracellular trap formation. FEBS Lett. 2013, 587, 2241-2246. [CrossRef]

76. Vegran, F.; Boidot, R.; Michiels, C.; Sonveaux, P.; Feron, O. Lactate influx through the endothelial cell monocarboxylate transporter MCT1 supports an NF-kappaB/IL-8 pathway that drives tumor angiogenesis. Cancer Res. 2011, 71, 2550-2560. [CrossRef]

77. Hojman, P.; Brolin, C.; Norgaard-Christensen, N.; Dethlefsen, C.; Lauenborg, B.; Olsen, C.K.; Abom, M.M.; Krag, T.; Gehl, J.; Pedersen, B.K. IL-6 release from muscles during exercise is stimulated by lactate-dependent protease activity. Am. J. Physiol. Endocrinol. Metab. 2019, 316, E940-E947. [CrossRef] 
78. Harada, N.; Hirano, I.; Inui, H.; Yamaji, R. Stereoselective effects of lactate enantiomers on the enhancement of 3T3-L1 adipocyte differentiation. Biochem. Biophys. Res. Commun. 2018, 498, 105-110. [CrossRef]

79. Harmon, D.L.; Britton, R.A.; Prior, R.L. In vitro rates of oxidation and gluconeogenesis from L(+)- and D(-)lactate in bovine tissues. Comp. Biochem. Physiol. B-Biochem. Mol. Biol. 1984, 77, 365-368. [CrossRef]

80. Enerson, B.E.; Drewes, L.R. Molecular features, regulation, and function of monocarboxylate transporters: Implications for drug delivery. J. Pharm. Sci. 2003, 92, 1531-1544. [CrossRef]

81. Graham, C.; Gatherar, I.; Haslam, I.; Glanville, M.; Simmons, N.L. Expression and localization of monocarboxylate transporters and sodium/proton exchangers in bovine rumen epithelium. Am. J. Physiol.-Regul. Integr. Comp. Physiol. 2007, 292, R997-R1007. [CrossRef] [PubMed]

82. Takahashi, S.; Saegusa, J.; Sendo, S.; Okano, T.; Akashi, K.; Irino, Y.; Morinobu, A. Glutaminase 1 plays a key role in the cell growth of fibroblast-like synoviocytes in rheumatoid arthritis. Arthritis Res. Ther. 2017, $19,76$. [CrossRef] [PubMed]

83. Wei, L.; Zhou, Y.; Yao, J.; Qiao, C.; Ni, T.; Guo, R.; Guo, Q.; Lu, N. Lactate promotes PGE2 synthesis and gluconeogenesis in monocytes to benefit the growth of inflammation-associated colorectal tumor. Oncotarget 2015, 6, 16198-16214. [CrossRef] [PubMed]

84. Korb, A.; Tohidast-Akrad, M.; Cetin, E.; Axmann, R.; Smolen, J.; Schett, G. Differential tissue expression and activation of p38 MAPK alpha, beta, gamma, and delta isoforms in rheumatoid arthritis. Arthritis Rheum. 2006, 54, 2745-2756. [CrossRef] [PubMed]

85. Schett, G.; Zwerina, J.; Firestein, G. The p38 mitogen-activated protein kinase (MAPK) pathway in rheumatoid arthritis. Ann. Rheum. Dis. 2008, 67, 909-916. [CrossRef]

86. Goodridge, H.S.; Harnett, W.; Liew, F.Y.; Harnett, M.M. Differential regulation of interleukin-12 p40 and p35 induction via Erk mitogen-activated protein kinase-dependent and -independent mechanisms and the implications for bioactive IL-12 and IL-23 responses. Immunology 2003, 109, 415-425. [CrossRef]

87. Thalhamer, T.; McGrath, M.A.; Harnett, M.M. MAPKs and their relevance to arthritis and inflammation. Rheumatology 2008, 47, 409-414. [CrossRef]

88. Xue, M.; McKelvey, K.; Shen, K.; Minhas, N.; March, L.; Park, S.Y.; Jackson, C.J. Endogenous MMP-9 and not MMP-2 promotes rheumatoid synovial fibroblast survival, inflammation and cartilage degradation. Rheumatology 2014, 53, 2270-2279. [CrossRef]

89. Xu, H.; He, Y.; Yang, X.; Liang, L.; Zhan, Z.; Ye, Y.; Yang, X.; Lian, F.; Sun, L. Anti-malarial agent artesunate inhibits TNF-alpha-induced production of proinflammatory cytokines via inhibition of NF-kappaB and PI3 kinase/Akt signal pathway in human rheumatoid arthritis fibroblast-like synoviocytes. Rheumatology 2007, 46, 920-926. [CrossRef]

90. Zhang, N.; Jiang, Y.; Mu, F.; Wu, H.; You, Q. Gentiopicrin exerts anti-rheumatic effect in human fibroblast-like synoviocytes via inhibition of p38MAPK/NF-kappaB pathway. Cell. Mol. Biol. (Noisy-Le-Grand) 2019, 65, 85-90. [CrossRef]

91. Luo, X.; Zuo, X.; Zhou, Y.; Zhang, B.; Shi, Y.; Liu, M.; Wang, K.; McMillian, D.R.; Xiao, X. Extracellular heat shock protein 70 inhibits tumour necrosis factor-alpha induced proinflammatory mediator production in fibroblast-like synoviocytes. Arthritis Res. Ther. 2008, 10, R41. [CrossRef]

92. Ni, S.; Li, C.; Xu, N.; Liu, X.; Wang, W.; Chen, W.; Wang, Y.; van Wijnen, A.J. Follistatin-like protein 1 induction of matrix metalloproteinase 1,3 and 13 gene expression in rheumatoid arthritis synoviocytes requires MAPK, JAK/STAT3 and NF-kappaB pathways. J. Cell. Physiol. 2018, 234, 454-463. [CrossRef] [PubMed]

93. Yoshida, S.; Katoh, T.; Tetsuka, T.; Uno, K.; Matsui, N.; Okamoto, T. Involvement of thioredoxin in rheumatoid arthritis: Its costimulatory roles in the TNF-alpha-induced production of IL-6 and IL-8 from cultured synovial fibroblasts. J. Immunol. 1999, 163, 351-358. [PubMed]

94. Arlier, S.; Kayisli, U.A.; Arici, A. Tumor necrosis factor alfa and interleukin 1 alfa induced phosphorylation and degradation of inhibitory kappa B alpha are regulated by estradiol in endometrial cells. Turk. J. Obs. Gynecol. 2018, 15, 50-59. [CrossRef]

95. Georganas, C.; Liu, H.; Perlman, H.; Hoffmann, A.; Thimmapaya, B.; Pope, R.M. Regulation of IL-6 and IL-8 expression in rheumatoid arthritis synovial fibroblasts: The dominant role for NF-kappa B but not C/EBP beta or c-Jun. J. Immunol. 2000, 165, 7199-7206. [CrossRef] 
96. Bramley, E.; Lean, I.J.; Fulkerson, W.J.; Costa, N.D. Clinical acidosis in a Gippsland dairy herd. Aust. Vet. J. 2005, 83, 347-352. [CrossRef]

97. Andersson, L.; Liberg, P. Blood serum and synovial fluid in bovine laminitis and arthritis, with particular reference to the protein composition. Acta Vet. Scand. 1980, 21, 567-577.

Publisher's Note: MDPI stays neutral with regard to jurisdictional claims in published maps and institutional affiliations.

(C) 2020 by the authors. Licensee MDPI, Basel, Switzerland. This article is an open access article distributed under the terms and conditions of the Creative Commons Attribution (CC BY) license (http://creativecommons.org/licenses/by/4.0/). 